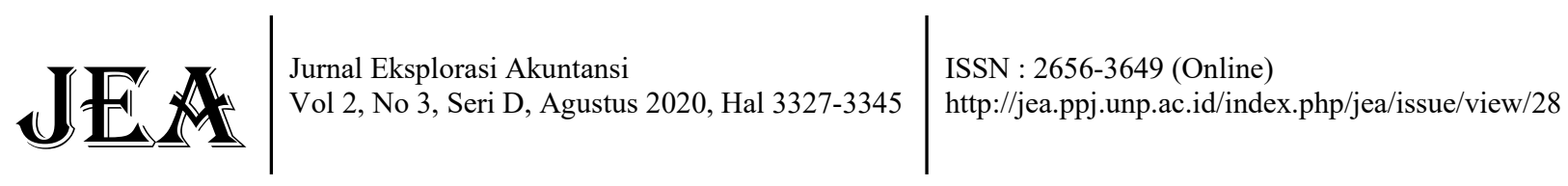

\section{PENGARUH KINERJA LINGKUNGAN DAN BIAYA LINGKUNGAN TERHADAP PROFITABILITAS PADA PERUSAHAAN MANUFAKTUR YANG TERDAFTAR DI BURSA EFEK INDONESIA TAHUN 2014-2018}

\author{
Marini Asjuwita ${ }^{1}$, Henri Agustin ${ }^{2}$ \\ ${ }^{1}$ Alumni Jurusan Akuntansi Fakultas Ekonomi, Universitas Negeri Padang \\ ${ }^{2}$ Jurusan Akuntansi Fakultas Ekonomi, Universitas Negeri Padang \\ *Korespondensi: mariniasjuwita08@gmail.com
}

\begin{abstract}
This study aims to analyze the effect of environmental performance on the level of profitability on manufacturing companies listed on the Stock Exchange in 2014-2018, analyze the effect of environmental costs on the level of profitability on manufacturing companies listed on the Stock Exchange in 2014-2018, and analyze the influence of environmental performance and costs environment has a joint influence on the level of profitability of manufacturing companies listed on the Indonesia Stock Exchange in 2014-2018 ... The results of this sprove that (1) Environmental performance has no positive effect on prof tudy itability on manufacturing companies listed on the Indonesia Stock Exchange in 2014-2018. (2) Environmental costs do not have a positive effect on profitability on manufacturing companies listed on the Indonesia Stock Exchange in 2014-2018.
\end{abstract}

Keywords: enviromental performance, PROPER, enviromental cost, financial performance, and return on assets.

How to cite (APA $6^{\text {th }}$ style):

Asjuwita, M., \&Agustin, H. (2020).Pengaruh Kinerja Lingkungan Dan Biaya Lingkungan Terhadap Profitabilitas Pada Perusahaan Manufaktur Yang Terdaftar Di Bursa Efek Indonesia Tahun 2014-2018. Jurnal Eksplorasi Akuntansi, 2(3), Seri D, 3327-3345.

\section{PENDAHULUAN}

Perusahaan merupakan sebuah organisasi yang melaksanakan kegiatan operasi dengan menggunakan sumber daya yang terbatas untuk mencapai tujuannya. Sering kali perusahaan mengabaikan masalah lingkungan dalam melaksanakan kegiatannya, hal ini membuat perusahaan merasakan dampak yang besar yang nantinya bisa mengancam keberlangsungan (sustainability) usahanya. Dalam hal ini konsep Corporate Social Responsibility hadir sebagai proses untuk megkomunikasikan dampak sosial dan lingkungan dari kegiatan ekonomi organisasi terhadap kelompok khusus yang berkepentingan dan terhadap masyarakat secara keseluruhan. 
Perhatian masyarakat yang semakin luas terhadap pentingnya tanggungjawab social perusahaan, dikarenakan banyak dari perusahaan yang menimbulkan dampak negative dari proses operasional perusahaan terhadap lingkungan yang sudah tidak dapat ditolerir. Masyarakat mengharapkan perusahaan lebih pekat terhadap kegiatan yang meminimalkan resikopolusi serta penggunaan sumber daya alam secara efektif dan efisien (Scahaltengger\&Synnestvedt, 2002).

Profitabilitas merupakan salah satu indikator yang tercakup dalam informasi mengenai kinerja perusahaan jangka panjang. Kinerja keuangan tersebut dapat dilihat melalui analisis laporan keuangan, tingkat profitabilitas digunakan sebagai dasar untuk mengukur kinerja keuangan perusahaan, hal ini dilakukan mengingat daya tarik bisnis merupakan salah satu indikator penting dalam persaingan usaha, sedangkan daya tarik bisnis dapat diukur dari profitabilitas usaha seperti ROA.

Return on Assets (ROA) dalam analisis manajemen keuangan, mempunyai arti yang sangat penting sebagai salah satu teknik analisis keuangan yang bersifat menyeluruh atau komprehensif. Rasio ini mengukur efektivitas perusahaan dengan keseluruhan dana yang ditanamkan dalam aktiva yang akan digunakan untuk operasi perusahaan dalam menghasilkan keuntungan (Munawir, 2005).

PROPER merupakan salah satu upaya untuk mendorong penataan perusahaan dalam pengelolaan lingkungan hidup melalui instrumen informasi, yang diarahkan untuk mendorong perusahaan untuk menaati peraturan perundang-undangan melalui insentif dan disentif reputasi, dan mendorong perusahaan yang sudah baik kinerja lingkungannya untuk menerapkan produksi bersih (cleaner production). Peringkat pada PROPER adalah emas, hijau, biru, merah dan hitam.

Keprihatinan terhadap semakin memburuknya kondisi lingkungan dan sosial akibat aktivitas bisnis perusahaan juga telah menjadi perhatian utama pada saat ini (Moser, Martin, 2012). Isu utama yang belum terpecahkan dalam penelitian akuntansi sosial dan lingkungan adalah hubungan antara tingkat pengungkapan dan tingkat kinerja dari CSR tersebut.

Peserta dalam PROPER terdiri dari beberapa sektor perusahaan di Indonesia, yaitu dari perusahaan manufaktur, industri jasa, dan penghasil bahan baku atau pengelola sumber daya alam. Perusahaan yang terdaftar di Bursa Efek Indonesia (BEI) dan menjadi peserta PROPER banyak berasal dari perusahaan manufaktur, karena perusahaan manufaktur lebih mudah terpengaruh oleh kondisi ekonomi dan memiliki tingkat sensitifitas yang tinggi terhadap setiap kejadian baik internal maupun eksternal perusahaan.

Perusahaan manufaktur di dalam operasinya selain menghasilkan produk, juga menghasilkan limbah. Hal ini disebabkan oleh adanya inefisensi yang dipahami dalam operasi perusahaan tersebut. Konsep mengenai pengelolaan lingkungan yang dipahami perusahaan adalah terbatas pada pengelolaan limbah yang dihasilkan dari proses produksi, tanpa adanya pertimbangan untuk mengubah proses produksi agar limbah yang dihasilkan dapat dikurangi (Agustia, 2010)

Di lain sisi perusahaan menganggap biaya lingkungan akan menjadi akun pengurang laba bagi perusahaan. Padahal, dengan adanya alokasi biaya untuk pengelolaan lingkungan memberikan konsistensi kepedulian lingkungan yang dilakukan perusahaan hingga dapat membangun kepercayaan masyarakat tentang tanggung jawab sosial perusahaan. Biaya lingkungan tersebut dapat dikatakan sebagai investasi jangka panjang bagi perusahaan. Hal ini karena dana yang dikeluarkan saat ini dapat memberikan nama baik bagi perusahaan hingga bisa menambah kepercayaan stakeholder pada perusahaan.

Fenomena yang terjadi saat ini adalah banyak perusahaan yang menjadikan kinerja lingkungan untuk memperbaiki citra perusahaan dimata publik atau masyarakat. Selain itu 
kinerja lingkungan yang dilakukan perusahaan dalam bentuk program CSR dapat dijadikan sebagai window dressing, ketika digunakan untuk kepentingan pribadi manajer atau egosime ekonomis perusahaan.

Selain itu perusahaan manufaktur yang ada di indonesia masih belum secara maksimal memanfaatkan program CSR yang ada, serta belum tepat sasaran terhadap tujuan dari program CSR yang dilakukan perusahaan sebagai salah satu wujud kinerja lingkungan. Perusahaan mungkin melakukan aktivitas kinerja lingkungan atau CSR secara intensif untuk menutupi beberapa kinerja korporasi yang melanggar aturan. Penelitian terdahulu masih terdapat GAP research dimana hasil yang tidak konsisten dari penelitian sebelumnya, serta masih terdapat ketidakpastian hubungan atau korelasi antara kinerja lingkungan terhadap profitabilitas maupun biaya lingkungan dengan profitabilitas.

Fenomena yang terjadi juga menunjukkan bahwa biaya lingkungan yang ditimbulkan dari program atau kinerja lingkungan perusahaan juga dapat dijadikan sebagai salah satu indikator dalam proses manajemen laba di dalam pelaporan keuangan. Sebab dengan adanya manajemen laba pada komponen biaya lingkungan maka akan dapat membuat perusahaan seolah-olah sukses dalam melaksanakan program CSR yang telah dijalankan agar dapat lebih meyakinkan dari para investor (stakeholder) untuk dapat berinvestasi serta berkontribusi pada perusahaan (Prior et al, 2008).

Alasan lainnya juga masih terdapat beberapa masalah yang terjadi terkait penyusunan dalam biaya lingkungan yang dikelurkan oleh perusahaan. Banyak diantara perusahaan manufaktur yang ada tidak memisahkan biaya lingkungan dengan biaya operasional perusahaan. Untuk itu, selanjutnya peneliti ingin menganalisis kembali Pengaruh Kinerja Lingkungan Dan Biaya Lingkungan Terhadap Profitabilitas Pada Perusahaan Manufaktur Yang Terdaftar Di Bursa Efek Indonesia Tahun 2014-2018.

\section{REVIU LITERATUR DAN HIPOTESIS Teori Legitimasi}

Teori legitimasi menyatakan bahwa organisasi atau perusahaan secara berkesinambungan harus memastikan apakah mereka telah beroperasi di dalam norma-norma yang dijunjung masyarakat dan memastikan bahwa aktivitas mereka bisa diterima pihak luar (dilegitimasi). Postulat dari teori legitimasi adalah organisasi bukan hanya harus terlihat memperhatikan hak-hak investor namun secara umum juga harus memperhatikan hak-hak publik (Deegan dan Rankin, 1996).

Perusahaan menganggap keberadaan dan aktivitasnya mendapat status dari masyarakat atau lingkungan apabila perusahaan melakukan pengungkapan sosial, sehingga perusahaan akan beroperasi atau dikatakan terlegitimasi (Adhima, 2012). Dengan perusahaan yang dapat dikatakan sudah terlegitimasi maka citra atau nama baik perusahaan menjadi baik di mata masyarakat, apalagi membuat kepercayaan stakeholder pada perusahaan dapat bertambah. Legitimasi dapat juga dijadikan sebagai wahana dalam mengonstruksikan diri di tengah lingkungan masyarakat yang semakin maju (Hadi, 2011: 87).

\section{Teori Stakeholder}

Teori stakeholder menyatakan bahwa semua stakeholder mempunyai hak memperoleh informasi mengenai aktivitas perusahaan yang dapat mempengaruhi pengambilan keputusan mereka. Para stakeholder dapat memilih untuk tidak menggunakan informasi tersebut dan bahkan tidak dapat memainkan peran secara langsung dalam suatu perusahaan (Deegan, 2004). Hal ini disebabkan stakeholder dianggap dapat mempengaruhi tapi juga dapat dipengaruhi perusahaan. Dengan 
demikian, keberadaan suatu perusahaan sangat dipengaruhi oleh dukungan yang diberikan oleh stakeholder kepada perusahaan tersebut.

Stakeholder menurut Kasali (2003: 63) merupakan kelompok yang berada di dalam dan luar perusahaan yang berperan dalam menentukan keberhasilan perusahaan dan mempertaruhkan hidupnya pada perusahaan. Agoes \& Ardana (2014: 85) mengatakan bahwa teori stakeholder adalah peranan bisnis perusahaan yang tidak lagi terbatas dari beberapa pemangku kepentingan saja, kini perusahaan dianggap sebagai lembaga sosial yang dapat memberikan manfaat dan kesejahteraan pada semua pemangku kepentingan. Maka disimpulkan bahwa stakeholder merupakan pihak yang mempengaruhi ataupun dipengaruhi perusahaan yang berperan dalam menentukan keberhasilan perusahaan itu sendiri. Hubungan antara stakeholder dengan perusahaan ini saling bergantung.

\section{Green Accounting}

Konsep sistem akuntansi lingkungan dapat diterapkan oleh perusahaan dalam skala yang besar maupun skala kecil dalam setiap industri dalam sektor manufaktur dan jasa. Penerapan akuntansi lingkungan harus dilakukan dengan sistematis atau didasarkan pada kebutuhan perusahaan. Keberhasilan dalam penerapan akuntansi lingkungan terletak pada komitmen manajemen dan keterlibatan fungsional. Sebuah perusahaan tidaklah terlepas dari tanggung jawab lingkungan, karena itu diperlukan suatu cara untuk mengintegralkan biaya lingkungan misalnya konsep eksternalitas dimana konsep ini melihat dampak langsung aktivitas suatu entitas terhadap lingkungan sosial, non-sosial dan ekologis.

Langkah awal yang dapat dilakukan terkait biaya lingkungan adalah dengan mengkategorikan jenis biaya terkait dengan memperhatikan beberapa aspek seperti lokasi situs limbah, jenis limbah berbahaya, metode pembuangan, dan lainnya. Biaya lingkungan mengandung biaya yang eksplisit dan implisit. Biaya implisit seperti biaya yang timbul akibat potensi kewajiban yang muncul.

Sistem penilaian biaya lingkungan dapat membantu memperbaiki keputusan-keputusan yang terkait dengan keputusan pembauran produk, pemilihan input produksi, penilaian pencegahan pencemaran, evaluasi pengelolaan limbah serta penentuan harga produk. Terdapat beberapa cara untuk mengetahui biaya-biaya lingkungan perusahaan yaitu dengan mengadopsi sistem akuntansi konvensional, activity based costing, full cost accounting dan total cost assessment.

\section{Kinerja Lingkungan}

Kinerja lingkungan adalah bagaimana kinerja perusahaan untuk ikut andil dalam melestarikan lingkungan. Kinerja lingkungan dibuat dalam bentuk peringkat dalam program oleh Kementrian Lingkungan Hidup (KLH) Republik Indonesia, yaitu PROPER (Program Penilaian Peringkat Kinerja dalam Pengelolaan Lingkungan Hidup). PROPER merupakan program pemeringkatan berdasarkan kinerja lingkungan tiap-tiap perusahaan, agar bisa dibandingkan dan menjadi koreksi bagi perusahaan tersebut.

Hasil dari PROPER ini adalah peringkat emas, hijau, biru, merah dan hitam. Perusahaan akan diberi penilaian warna emas apabila perusahaan tersebut telah melakukan pengelolaan lingkungan lebih dari yang dipersyaratkan dan melakukan upaya-upaya pengembangan masyarakat secara berkesinambungan. Penilaian warna hijau adalah untuk perusahaan yang telah melakukana pengelolaan lingkungan lebih dari yang dipersyaratkan, telah mempunyai 
keanekaragaman hayati, sistem manajemen lingkungan, 3R limbah padat, 3R limbah B3, konservasi penurunan beban pencemaran air, penurunan emisi dan efisiensi energi.

\section{Biaya Lingkungan \\ 1. Biaya Lingkungan}

Biaya lingkungan adalah biaya-biaya yang terjadi karena kualitas lingkungan yang buruk atau kualitas lingkungan yang buruk yang mungkin terjadi (Hansen dan Mowen, 2009:413). Biaya lingkungan merupakan kos yang terjadi disebabkan adanya atau kemungkinan adanya kualitas lingkungan yang buruk (Sholihin, 2004). Susenohaji (2003) mengatakan biaya lingkungan merupakan biaya yang dikeluarkan perusahaan yang berhubungan dengan kerusakan lingkungan yang timbul dengan perlindungan yang dilakukan. Hansen \& Mowen (2009) juga mengemukakan bahwa biaya lingkungan merupakan biaya yang terjadi karena kualitas buruk lingkungan yang mungkin terjadi. Dari ketiga pengertian di atas dapat ditarik kesimpulan tentang pengertian biaya lingkungan, biaya lingkungan adalah biaya yang dikeluarkan perusahaan untuk mencegah kemungkinan adanya kualitas lingkungan buruk dan mengatasi kerusakan lingkungan yang timbul disebabkan aktivitas perusahaan.

\section{Indikator Pengukuran Biaya Lingkungan}

Biaya lingkungan dalam penelitian diukur dengan membandingkan biaya yang dikeluarkan perusahaan untuk kegiatan Corporate Social Responsibility dengan laba tahun berjalan. Sesuai dengan yang dikatakan Hadi (2011) dan Babalola (2012). Rumus yang dalam pengukuran biaya lingkungan adalah sebagai berikut :

$$
\text { Biaya Lingkungan }=\frac{\text { Cost }}{\text { Profit }}
$$

\section{Profitabilitas}

Pengertian profitabilitas menurut Sofyan Safri Hararap (2008) adalah profitabilitas menggambarkan kemampuan perusahaan mendapatakan laba melalui semua kemampuan perusahaan mendapatkan laba melalui semua kemampuan sumber daya yang ada seperti kegiatan penjualan, kas, modal, jumlah karyawan, jumlah cabang dan sebagainya. Profitabilitas dapat ditetapkan dengan menghitung berbagai tolak ukur yang relevan. Salah satu tolak ukur tersebut adalah dengan rasio keuangan sebagai salah satu analisa dalam menganalisa kondisi keuangan, hasil operasi dan tingkat profitabilitas perusahaan (Brigham dan Houston, 2006).

Rasio ini adalah rasio keuntungan bersih setelah pajak terhadap jumlah aktiva secara keseluruhan. Rasio ini merupakan suatu ukuran untuk menilai seberapa besar persentase tingkat pengembalian dari aktiva yang dimiliki. Apabila rasio ini tinggi berarti menujukkan adanya efisiensi yang dilakukan oleh pihak manejemen. Return on assets (ROA) digunakan untuk mengukur kemampuan perusahaan menghasilkan laba bersih berdasarkan tingkat aktiva tertentu. Rasio ini menunjukkan kemampuan sumber daya ekonomis yang diinvestasikan dalam keseluruhan aktiva untuk menghasilkan keuntungan bersih. Dengan kata lain, berapa laba yang diperoleh atas setiap rupiah yang tertanam dalam aktiva. Dalam perhitungan rasio ini, total aktiva yang digunakan adalah jumlah seluruh dari total aktiva (akhir tahun) selama periode perhitungan. Ini dikarenakan penggunaan jumlah keseluruhan total aktiva dapat rnemberi nilai tarnbah bagi investor untuk rnengetahui pertumbuhan, penurunan atau faktor signifikan lainnya dalam suatu bisnis. 
berikut:

Rumus untuk menghitung return on assets menurut Sugiono (2009,p:80) adalah sebagai

$$
\mathrm{ROA}=\frac{\text { Laba Bersih Setelah Pajak }}{\text { Total Aktiva }}
$$

Alasan dipilihnya return on asset (ROA) sebagai alat untuk penghitungan profitabilitas karaena rasio return on asset merupakan indikator penting dari laporan keuangan yang memiliki berbagai kegunaan. Rasio return on asset dapat digunakan untuk mengukur kemampuan perusahaan dalam memperoleh keuntungan (laba) secara keseluruhan.

\section{Penelitian Terdahulu}

Penelitian terkait Green beberapa kalangan tentang kinerja lingkungan dan biaya lingkungan terhadap profitabilitas. Penelitian Suhong Li (2017) dalam memahami dampak dari Green Accounting mengenai Kinerja Lingkungan terhadap Kinerja Keuangan di Amerika Serikat. Menguji 500 perusahaan publik di Amerika Serikat di sektor Manufaktur, penelitian terdahulu menggunakan proksi profitabilitas dengan ROS, ROA, dan Tobin's q.

Dessy (2015) juga menguji pengaruh kinerja lingkungan terhadap profitabilitas pada 17 perusahaan manufaktur infrastruktur dan jasa yang terdaftar di Bursa Efek Indonesia periode 2011-2013. Kinerja lingkungan sebagai variabel independen pada penelitian ini dinilai berdasarkan hasil PROPER 2011-2013 dan profitabilitas sebagai variabel dependen diukur berdasarkan Return On Equity (ROE). Hasil penelitian ini menunjukkan bahwa terdapat pengaruh yang signifikan antara kinerja lingkugan terhadap profitabilitas.

Sejalan dengan penelitian Camilia (2016) yang menggunakan sampel sebanyak 33 perusahaan manufaktur di Bursa Efek Indonesia dengan periode tahun 2011-2015. Berdasarkan hasil pengujian hipotesis pertama pada penelitian ini menunjukkan bahwa kinerja lingkungan memiliki pengaruh terhadap kinerja keuangan.Sedangkan untuk hasil pengujian kedua menujukkan bahwa tidak terdapat pengaruh antara biaya lingkungan terhadap kinerja keuangan. Persamaan penelitian terdahulu dengan penelitian ini adalah menggunakan kinerja lingkungan dan biaya lingkungan sebagai variabel independen. Untuk variabel dependen sama-sama menggunakan kinerja keuangan.

Selanjutnya Anis Fitriani (2013) meneliti perusahaan BUMN yang terdaftar di Bursa Efek Indonesia dengan periode tahun 2004-2011. Hasil penelitian ini menunjukkan bahwa kinerja lingkungan berpengaruh positif terhadap kinerja keuangan. Angela (2015) menggunakan sampel penelitian sebanyak 91 perusahaan manufaktur yang terdaftar di Bursa Efek Indonesia dnegan periode tahun 2010-2013. Hasil penelitian menunjukkan hasil bahwa kinerja lingkungan tidak berpengaruh positif terhadap kinerja keuangan.

Chang (2015) menguji menguji dampak kinerja lingkungan dan kecenderungan pengungkapan kinerja keuangan, bukti empiris panel data industri di Cina. Menguji dengan periode 2008-2012, kausalitas dengan nilai Tobin's Q menggunakan akar dari uji coba data panel. Lindrianasari (2016) menguji kegiatan pengelolaan lingkungan terhadap kinerja keuangan di pertambangan alat ukur yang dipakai adalah ROI dengan hasil bahwa tidak adanya pengaruh antara biaya lingkungan pada pertambangan. Penelitian terdahulu menggunakan 41 sampel penelitian yang terdiri dari semua perusahaan pertambangan di indonesia untuk periode 20112013. 


\section{Hubungan Antar Variabel dan Hipotesis Penelitian Pengaruh Kinerja Lingkungan terhadap Profitabilitas}

Kinerja lingkungan menjadi hal yang banyak mendapat perhatian dari masyarakat dikarenakan permasalahan yang menyangkut lingkungan hidup yang semakin menjadi isu global. Namun, kinerja lingkungan yang baik dapat membuat citra dan reputasi perusahaan menjadi lebih baik dimata publik (Haryati, 2013). Sesuai dengan teori yang dipakai peneliti yaitu teori stakeholder dengan tujuan utama teori ini untuk membantu manajemen perusahaan dalam mengingkatkan penciptaan nilai sebagai dampak dari aktivitas-aktivitas yang dilakukan hal ini yang membuat hubungan antara stakeholder dan perusahaan saling bergantung. Stakeholder membutuhkan perusahaan untuk memenuhi kepentingannya, sementara perusahaan juga membutuhkan stakeholder untuk mencapai keberhasilan dan menjaga kelangsungan perusahaannya (Ghazali, 2007).

Dengan demikian, semakin tinggi tingkat profitabilitas perusahaan yang dikelola maka kinerja lingkungan dapat dikatakan baik. Maka dari itu, laporan berkelanjutan diperlukan sebagai jawaban dari tuntutan stakeholder. Laporan berkelanjutan dapat membantu stakeholder untuk mengetahui kinerja perusahaan apakah perusahaan peduli dengan lingkungan dan memberikan respon positif terhadap profitabilitas atau bahkan sebaliknya seperti pada penelitian Dessy dan Rosita (2015), menemukan bahwa terdapat pengaruh antara kinerja lingkungan dengan profitabilitas. Berdasarkan penjelasan rumusan diatas, dirumuskan hipotesis sebagai berikut :

H1: Kinerja lingkungan berpengaruh positif terhadap profitabilitas

\section{Pengaruh Biaya Lingkungan terhadap Profitabilitas}

Perusahaan yang melakukan pengungkapan sosial akan merasa keberadaan dan aktivitasnya mendapat status dari masyarakat atau lingkungan, sehingga perusahaan tersebut beroperasi atau dapat dikatakan terlegitimasi (Adhima, 2012). Teori legitimasi terus menerus mencoba menyakinkan aktivitas yang dilakukan sesuai batasan dan norma masyarakat. Jika perusahaan yang tidak bisa memenuhi harapan stakeholder akan perhatian perusahaan terhadap masyarakat dan lingkungan, hal ini menandakan perusahaan belum terlegitimasi (Hadi, 2011).

Dengan demikian, biaya lingkungan ini bisa dikatakan sebagai investasi jangka panjang perusahaan, sebab dana yang dikeluarkan saat ini bisa memberikan nama baik bagi perusahaan. Hal ini sesuai dengan pendapat Camilia (2016) bahwa jika program bina lingkungan (yang berakibat biaya lingkungan) diterbitkan akan mampu meningkatkan reputasi yang berpengaruh pada keunggulan kompetitif dan dapat dijadikan sebagai strategi dalam meningkatkan omset penjualan atau laba perusahaan. Hal tersebut yang harus mulai dipertimbangkan, bukan hanya bagaimana memperoleh laba yang besar namun juga mempertimbangkan bagaimana cara memperoleh laba dengan memperhatikan aspek sustainability. Penelitian yang dilakukan Fitriani (2013) juga mendukung adanya pengaruh positif antara biaya lingkungan terhadap profitabilitas. Berdasarkan pendapat diatas, maka hipotesis dari penelitian ini adalah :

H2 : Biaya lingkungan berpengaruh positif terhadap profitabilitas

\section{METODE PENELITIAN}

\section{Pendekatan dan Jenis Penelitian}

Penelitian ini menggunakan metode penelitian kausatif, penelitian kausatif menurut Sugiono (2005) yaitu penelitian yang menyatakan hubungan sebab akibat. Pendekatan dasar kausatif melibatkan kegiatan peneliti yang diawali dari mengidentifikasi pengaruh variabel satu terhadap variabel lainnya kemudian berusaha mencari kemungkinan variabel penyebabnya. Jadi penelitian ini menggambarkan fakta-fakta yang terjadi secara jelas dan melihat pengaruh dari masing- 
masing variabel penyebab atau variabel independen $(\mathrm{X})$ terhadap variabel akibat atau variabel dependen (Y).

\section{Populasi dan Sampel Penelitian}

Populasi dalam penelitian ini adalah perusahaan manufaktur yang terdaftar di Bursa Efek Indonesia (BEI) dan dipublikasikan di website www.idx.co.idpada tahun 2014 - 2018. Populasi dalam penelitian ini berjumlah 148perusahaan. Dalam penelitian ini metode penentuan sampel yang digunakan adalah purposive sampling yaitu teknik penentuan sampel dengan pertimbangan tertentu (Sugiyono, 2008). Dimana beberapa kriteria sampel yang digunakan adalah sebagai berikut:

a. Merupakan perusahaan perusahaan yang terdaftar di Bursa Efek Indonesia selama periode 2014 - 2018, jika perusahaan baru terdaftar pada tahun tersebut atau delisting pada tahun tersebut maka perusahaan tidak dapat dijadikansampel.

b. Perusahaan yang memiliki data laporan keuangan dengan mata uang rupiah dan memiliki laporan tahunan lengkap selama periode 2014 - 2018 yang diperlukan dalampenelitian.

c. Perusahaan yang mengikuti Program Penilaian Peringkat Kinerja Lingkungan Hidup selama periode 2014 - 2018.

\section{Metode Pengumpulan Data}

Jenis data yang digunakan dalam penelitian ini adalah data sekunder yang merupakan sumber data penelitian yang diperoleh peneliti melalui media internet dari website Indonesia Stock Exchange (IDX), www.idx.co.iddan website perusahaan yaitu berupa laporan keuangan, laporan tahunan dan laporan berkelanjutan perusahaan manufaktur periode $2014-2018$.

Metode yang digunakan dalam pengumpulan data untuk melakukan penelitian ini adalah data yang sudah tersedia (available data) dan dokumentasi. Data yang tersedia diperoleh dari laporan keuangan, laporan tahunan dan laporan keberlanjutan perusahaan dimana item yang dilihat dari laporan tersebut berupa laporan hasil dari Kementerian Lingkungan Hidup dimana akan dibuat daftar untuk mengumpulkan data. Sedangkan dokumentasi dilakukan dengan cara mengumpulkan data, mencatat dan mengkaji data sekunder berupa laporan keuangan perusahaan yang telah dipublikasikan dalam periode pengamatan.

\section{Jenis dan Pengukuran Variabel}

Variabel dalam penelitian ini terdiri dari satu variabel dependen dan variabel independen. Variabel dependennya adalah profitabilitas, sedangkan variabel independennya berupa kinerja lingkungan dan biaya lingkungan.

\section{Variabel Dependen}

Variabel dependen merupakan variabel yang menjadi perhatian utama peneliti (Sekaran, 2011: 116). Adapun variabel dependen dalam penelitian ini adalah profitabilitas. Profitabilitas dalam penelitian ini diukur menggunakan ROA (Return on Assets) dengan rumus dalam Brigham \& Houston (2010: 148) yaitu:

$$
\mathrm{ROA}=\underline{\text { Laba Bersih }}
$$

Total Aset 


\section{Variabel Independen}

Variabel independen adalah variabel yang mempengaruhi variabel terikat (variabel dependen), baik secara positif atau negatif (Sekaran, 2011: 116). Adapun dalam penelitian ini terdapat dua variabel independen yaitu kinerja lingkungan dan biaya lingkungan.

a. KinerjaLingkungan

Penilaian kinerja lingkungan ini menggunakan laporan PROPER yang secara resmi diterbitkan oleh Kementerian Lingkungan Hidup. Penilaian kinerja lingkungan melalui PROPER ini dengan memberikan skor dari peringkat yang diproksikan dengan angka 5-1. Peringkat PROPER ini dikelompokkan dalam 5 (lima) peringkat warna yaitu EMAS, HIJAU, BIRU, MERAH, dan HITAM.

b. Biaya Lingkungan

Biaya lingkungan dapat dihitung dengan membandingkan biaya-biaya yang dikeluarkan untuk kegiatan Corporate Social Responsibility perusahaan dengan laba bersih. Hal tersebut sesuai dengan pendapat Hadi (2011) dan Babalola (2012).

$$
\text { Biaya Lingkungan }=\frac{\text { Cost }}{\text { Profit }}
$$

\section{HASIL PENELITIAN DAN PEMBAHASAN \\ Hasil Penelitian}

Penelitian ini menganalisis pengaruh kinerja lingkungan, biaya lingkungan terhadap profitabilitas perusahaan manufaktur yang ada di BEI periode 2014-2018.

\section{Statistik Deskriptif}

Analisis deskriptif yang diambil untuk penelitian ini dimulai dari tahun 2014 sampai tahun 2018 yakni sebanyak 101 data pengamatan. Sedangkan deskripsi variabel dalam statistik deskriptif pada penelitian ini menggunakan nilai minimum, nilai maksimum, mean, dan standar deviasi.

a. Profitabilitas

Profitabilitas adalah gambaran tentang kondisi keuangan pada suatu perusahaan dalam periode tertentu yang dianalisis dengan menggunakan alat-alat analisis keuangan. Profitabilitas dalam penilitian diukur menggunakan Return On Asset (ROA). Rasio ini akan menggambarkan kemampuan perusahaan dalam menghasilkan laba melalui seluruh aset dan aktiva yang dimiliki oleh perusahaan (Sutrisno, 2001).

\section{Tabel 2}

Hasil Statistik Deskriptif Profitabilitas

N Minimum Maximum Mean Std. Deviation

\begin{tabular}{llllll}
\hline Profitabilitas & 101 &,- 06 & 1,39 &, 1355 &, 23487 \\
\hline
\end{tabular}

Valid N (listwise) 101

Sumber: Data Sekunder diolah, Tahun 2020 
Berdasarkan Tabel 2 kinerja keuangan berkisar antara -0,06-1,39 dengan nilai mean 0,1355 dan standar deviasi sebesar 0,23487. Sementara untuk perusahaan yang memiliki profitabilitas terendah pada penelitian ini adalah PT. Gunawan Dianjaya Steel Tbk. (GDST) tahun 2018, dan nilai profitabilitas tertinggi adalah PT. Ultra Jaya Milk Industry \& Tra (ULTJ) pada tahun 2017. Untuk mean, hasil analisis deskriptif disini menunjukkan angka 0,1355 yang artinya profitabilits perusahaan selama periode penelitian ini memiliki hasil yang cukup baik. Apabila dibangdingkan dengan standar deviasi, mean profitabilitas lebih kecil dari standar deviasi 0,23487, ini berarti tingkat variasi sangat tinggi dan datanya lebih heterogen. Perkembangan profitabilitas setiap tahunnya dapat dilihat sebagai berikut :

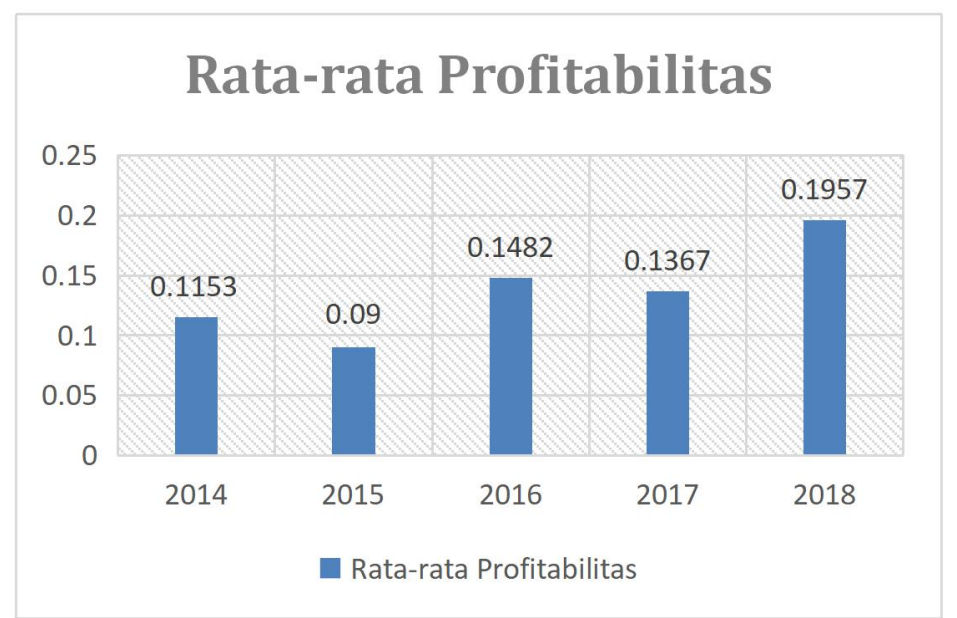

Sumber: Data sekunder diolah, Tahun 2020

Gambar 1. Diagram Rata-rata Profitabilitas

Gambar 1 menunjukkan mean Profitabilitas untuk 101 sampel perusahaan manufaktur periode 2014-2018. Terlihat Rata-rata Profitabilitas perusahaan mengalami fluktuasi selama periode penelitian. Pada tahun 2015, mean Profitabilitas menurun sebesar 3\% dari tahun sebelumnya, dan pada tahun 2016 mean Profitabilitas naik sebesar 6\%. Untuk tahun 2017 mean Profitabilitas turun lagi sekitar 1\%, namun di tahun 2018 kenaikan cukup tinggi terjadi yakni sebesar $6 \%$ dari tahun sebelumnya.

b. Kinerja Lingkungan

Hasil analisis deskriptif kinerja lingkungan diukur melalui PROPER, disini terlihat bahwa nilai minimum-nya adalah 2 , ini merupakan peringkat paling rendah selama 5 periode penelitian ini sehingga berwarna Merah. Untuk nilai maksimumnya adalah 4 yang berarti peringkat terbaik yang ditunjukkan dengan warna Hijau. menurut PROPER selama periode penelitian. Rata-rata hasil PROPER menunjukkan angka 2,97 yang menunjukkan peringkat PROPER berwarna Biru.

Tabel 3

Hasil Statistik Deskriptif PROPER

\begin{tabular}{llllll}
\hline Descriptive Statistics & $\mathrm{N}$ & Minimum & Maximum & Mean & Std. Deviation \\
\hline Kinerja Lingkungan & 101 & 2,00 & 4,00 & 2,9703 &, 41123 \\
\hline Valid N (listwise) & 101 & & & & \\
\hline Sumber Data & & & & & \\
\hline
\end{tabular}

Sumber: Data sekunder diolah, Tahun 2020 


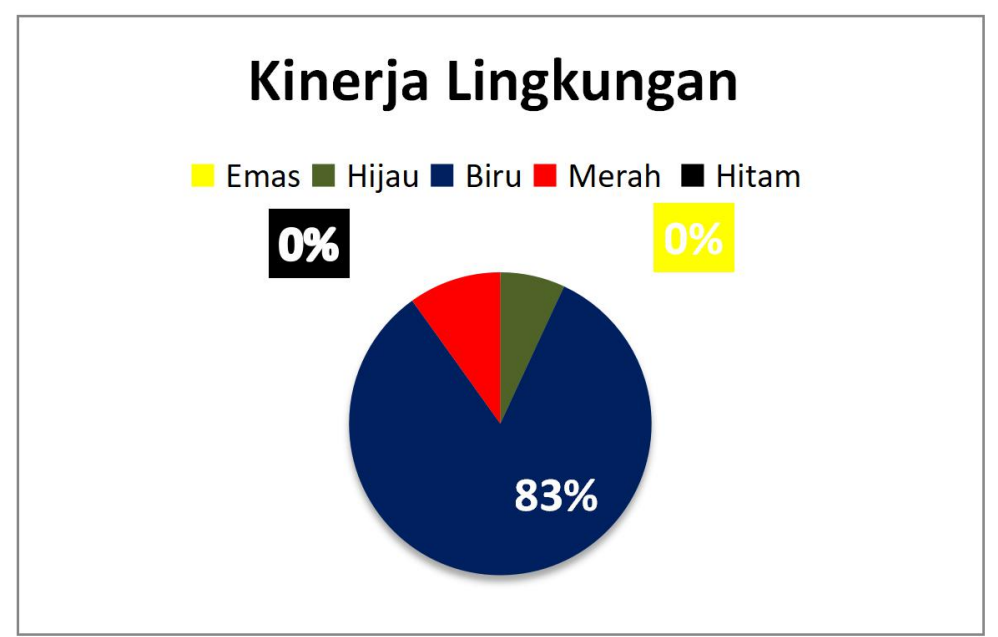

Sumber: Data sekunder diolah, Tahun 2020

Gambar 2

Diagram Pie Kategori PROPER

Pada gambar 2 diatas, dapat diketahui bahwa selama 5 periode penelitian secara keseluruhan perusahaan mendapatkan peringkat PROPER kategori warna BIRU sebesar $83 \%$. Jumlah perusahaan dengan kategori peringkat bewarna BIRU ini sebanyak 84 perusahaan dari 101 sampel selama periode penelitian yang telah melakukan pengelolaan lingkungan dengan baik. Selanjutanya adalah kategori Hijau persentase sebesar 7\% dengan jumlah 7 perusahaan yaitu Semen Indonesia Persero TBK (SMGR) berturut-turut selama tahun 2015-2018. Kesimpulannya, pada penelitian ini, kategori peringkat berwarna Biru memiliki posisi tertinggi daripada kategori warna lain. Apabila dilihat dari perkembangan PROPER setiap tahun menunjukkan sebagai berikut:

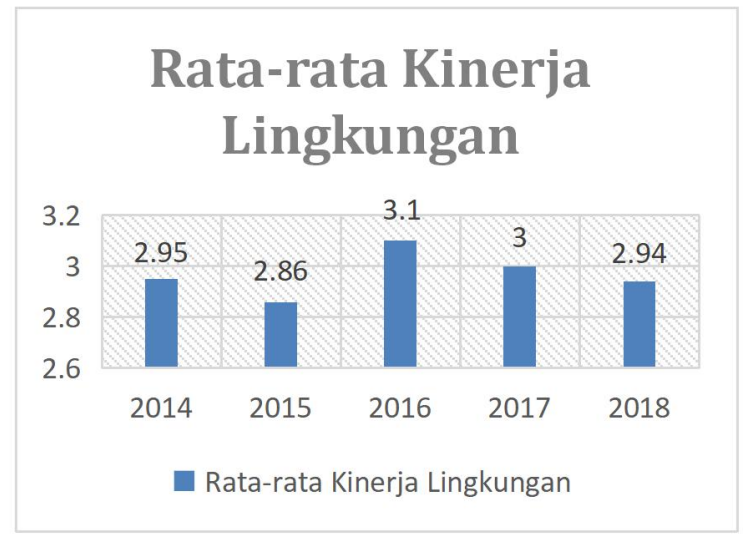

Sumber: Data sekunder diolah, Tahun 2020

\section{Gambar 3. Rata-rata Kinerja Lingkungan}

Pada gambar 3 dapat dilihat pada tahun 2015 mengalami penurunan sebesar 9\% dari tahun sebelumnya. Pada tahun 2016 sempat mengalami kenaikan yang cukup signifikan dari tahun 2015 yaitu sebesar 24\%. Setelah mengalami kenaikan yang cukup tinggi namun berbanding terbalik untuk tahun 2017-2018 yang terus mengalami penurunan sebesar 6\%-10\%, keadaan tersebut terjadi karena jumlah perusahaan yang mengikuti PROPER cukup berkurang. 
Dapat disimpulkan bahwa selama 5 (lima) tahun mengalami fluktuasi cukup baik hanya saja ada beberapa perusahaan yang kurang baik dalam melaporkan.

c. Biaya Lingkungan

\section{Tabel 4}

Hasil Statistik Deskriptif Biaya Lingkungan Descriptive Statistics

\begin{tabular}{llllll}
\hline & $\mathrm{N}$ & Minimum & Maximum & Mean & Std. Deviation \\
\hline Biaya Lingkungan & 101 &,- 31 &, 43 &, 0168 &, 06537 \\
\hline Valid N (listwise) & 101 & & & & \\
\hline
\end{tabular}

Sumber: Data sekunder diolah, Tahun 2020

Pada tabel 4 terlihat bahwa dari 101 sampel yang diuji, nilai minimumnya adalah $-0,31$. Nilai minimum didapat dari hasil perhitungan biaya lingkungan milik PT. Gunawan Dianjaya Steel Tbk (GDST) tahun 2017 yang mengalami kerugian bersih sebesar Rp. (-5.462.096.177). Sedangkan nilai maksimumnya sebesar 0,43 yang didapat dari hasil perhitungan biaya lingkungan PT. Multi Bintang Indonesia Tbk (MLBI) tahun 2018. Untuk rata-rata keseluruhan biaya lingkungannya adalah 0,0168 lebih kecil dari standar deviasi sebesar 0,06537, ini berarti tingkat variasi sangat tinggi dan datanya cenderung heterogen. Berikiut dapat dilihat hasilnya :

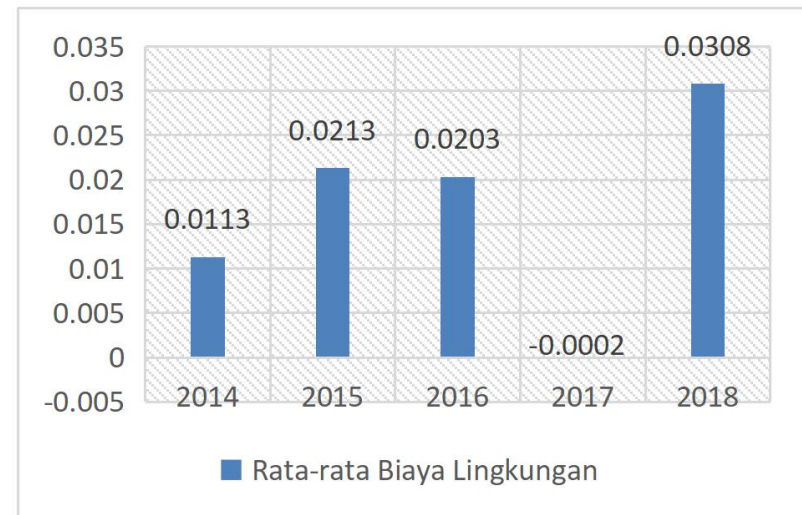

Sumber: Data sekunder diolah, Tahun 2020

\section{Gambar 4}

\section{Rata-rata Biaya Lingkungan}

Pada gambar 4tahun 2014, rata-rata biaya lingkungan yang dihasilkan sebesar 0,0113 dan rata-rat tahun 2015 mengalami peningkatan yang cukup tinggi sebesar 0,0213 atau 1\% dari tahun sebelumnya, namun pada tahun 2016-2017 mengalami penurunan yang sangat drastis yaitu tahun 2016 turun menjadi 0,1\% dan tahun 2017 sebesar -0,02\%. Sedangkan pada tahun 2018 mengalami kenaikan yang sangat jauh dari tahun sebelumnya yaitu sebesar 3\%. Hal ini menunjukkan kesimpulan bahwa, rata-rata biaya lingkungan mengalami fluktuasi karena terdapat beberapa perusahaan menghasilkan minus pada beberapa periode penelitian.

\section{Hasil Uji Asumsi Klasik}

\section{Uji Normalitas}

Hasil uji normalitas menggunakan One-Sample Kolmogrov-Smirnov Test adalah 1,196 dan Asymp.Sig. (2-tailed) adalah 0,114. Hasil uji normalitas dengan signifikansi 0,114>0,05 
menunjukkan $\mathrm{H}_{0}$ diterima yang artinya data residual terdistribusi secara normal.

2. Uji Multikolinearitas

Hasil uji Multikolinearitas yang dilakukan pada variabel Kinerja Lingkungan, Biaya Lingkungan menunjukkan tidak ada variabel independen yang memiliki nilai tolerance kurang dari 0,1 artinya tidak ada korelasi antar variabel independen yang nilainya lebih dari 95\%. Hasil perhitungan VIF (variance Inflation Factor) menunjukkan tidak ada variabel independen yang memiliki nilai VIF lebih dari 10.sehingga, hasilya menunjukkan tidak ada Multikolinearitas antar variabel independen.

3. Uji Autokorelasi

Berdasarkan pengujian dengan nilai Durbin-Watson adalah 2,160. Nilai tersebut dibandingkan dengan nilai dU dan $4-\mathrm{dU}$. Nilai dU diambil dari tabel Durbin-Watson dengan $\mathrm{n}=90$ dan $\mathrm{k}$ $=2$, dan diperoleh dU sebesar 1,7026. Selanjutnya dilakukan pengambilan keputusan dengan ketentuan $\mathrm{dU}<\mathrm{d}<4-\mathrm{dU}(1,7026<2,160<2,2974)$. Sehingga dapat disimpulkan bahwa tidak terjadi Autokorelasi antara variabel independen sehingga layak untuk digunakan.

4. Uji Heteroskedasitisitas

Hasil uji heterokedastisitas memberikan koefisien parameter bahwa variabel indepeden kinerja lingkungan dengan biaya lingkungan tidak ada yang signifikan atau lebih besar dari 0,05, sehingga dapat disimpulkan bahwa model regresi tidak terdapat Heteroskedastisitas.

\section{Uji Linearitas}

Hasil uji linieritas menunjukkan nilai R2 ( $R$ Square) sebesar 0,012 dengan jumlah $\mathrm{n}=90$, maka besarnya nilai $\mathrm{c}^{2}$ hitung $=90 \times 0,012=1,08$. Nilai ini dibandingkan dengan $\mathrm{c}^{2}$ tabel $\mathrm{df}=87$ dan tingkat signifikansi 0,05 didapat nilai $\mathrm{c}^{2}$ tabel $=1,98761$. Oleh karena nilai $\mathrm{c}^{2}$ hitung lebih kecil dari $\mathrm{c}^{2}$ tabel maka dapat disimpulkan bahwa model yang benar adalah model linear.

\section{Uji Analisis Regresi}

Uji Determinasi $\left(\mathrm{R}^{2}\right)$

Berdasarkan hasil uji determiasi, besarnya adjusted $\mathrm{R}^{2}$ adalah $-0,010$ artinya $1 \%$ variasi profitabilitas dapat dijelaskan dengan variabel dari variabel independen yaini Kinerja Lingkungan dan Biaya Lingkungan sisanya $(100 \%-1 \%=99 \%)$ dijelaskan oleh sebab-sebab lain diluar model.

Uji F

Berdasalkan hasil uji $\mathrm{F}$ atau ANOVA didapatkan nilai $\mathrm{F}$ hitung sebesar 0,546 dengan nilai signifikansi 0,581. Karena nilai signifikansi 0,581>0,05, sehingga disimpulkan bahwa Kinerja Lingkungan dan Biaya Lingkungan tidak berpengaruh secara bersamaan terhadap Profitabilitas.

\section{Uji T}

Berdasarkan hasil uji t, terlihat bahwa nilai signifikan variabel penjelas/independen Kinerja Lingkungan sebesar 0,506 karena nilai signifikansi 0,506>0,05 maka disimpulkan bahwa variable Kinerja Lingkungan tidak berpengaruh terhadap variabel dependen Profitabilitas (ROA). Variabel independen lain yakni Biaya Lingkungan menunjukkan hasil 0,476 karena nilai signifikansi 0,476>0,05 sehingga disimpulkan bahwa variabel Biaya Lingkungan tidak berpengaruh terhadap variabel dependen Profitabilitas (ROA). 


\section{Hasil Uji Hipotesis}

Berdasarkan hasil uji hipotesis, hasil pengujian hipotesis pertama dengan menggunakan variabel Kinerja Lingkungan diperoleh nilai t-hitung sebesar 0,668dan nilai signifikan sebesar 0,506. Proses pengolahan data dilakukan dengan menggunakan tingkat kesalahan sebesar 0,05 . Hasil yang diperoleh tersebut menunjukkan bahwa nilai signifikan sebesar 0,506> alpha 0,05 maka dapat disimpulkan bahwa kinerja lingkungantidak berpengaruh positif terhadap profitabilitas pada perusahaan manufaktur di Bursa Efek Indonesia.

Perusahaan yang mengungkapan kinerja lingkungan pada laporan keuangan atau yang terdapat pada laporan lain seperti PROPER, nilai perusahaan yang menjelaskan kinerja lingkungan dinilai lebih baik dalam operasionalnya dari pada yang tidak mengungkapkan. Semakin tinggi tingkat profitabilitas perusahaan yang dikelola maka kinerja lingkungan dapat dikatakan baik. Namun dapat diasumsikan bahwa tingkat profitabilitas perusahaan yang dikelolamasih belum berpengaruh positif terhadap kinerja lingkungan seperti penelitian yang dilakukan oleh Angela (2015) yang menunjukkan bahwa kinerja lingkungan tidak berpengaruh positif terhadap pengungkapan kinerja keuangan.

Sesuai dengan hasil pengujian hipotesis kedua dengan menggunakan variabel biaya lingkungan diperoleh nilai t-hitung sebesar 0,716 dengan nilai signifikan sebesar 0,476. Proses pengolahan data dilakukan dengan menggunakan tingkat kesalahan sebesar 0,05. Hasil yang diperoleh tersebut menunjukkan bahwa nilai signifikan sebesar 0,476> alpha 0,05 dapat disimpulkan bahwa biaya lingkungan tidak berpengaruh positif terhadap profitabilitas pada perusahaan manufaktur di Bursa Efek Indonesia.

Biaya lingkungan merupakan biaya yang dikeluarkan perusahaan untuk pencegahan kemungkinan kualitas lingkungan yang buruk dan mengatasi kerusakan lingkungan yang timbul oleh aktivitas perusahaan. Perusahaan berusaha menyajikan informasi terkait biaya lingkungan sebagai bukti bahwa perusahaan bertanggung jawab terhadap lingkungan. Serta diharapkan dapat menjadi investasi jangka panjang perusahaan, karena dana yang dikeluarkan memberikan nama baik bagi perusahaan. Jika program bina lingkungan diterbitkan dapat meningkatkan reputasi yang berpangaruh terhadap keunggulan kompetitif dan dapat dijadikan untuk strategi dalam meningkatkan omset penjualan. Namun dapat diasumsikan bahwa biaya lingkunganmasih belum berpengaruh positif terhadap profitabilitas seperti penelitian yang dilakukan oleh Camilia (2016) yang juga menujukkan bahwa tidak terdapat pengaruh antara biaya lingkungan terhadap kinerja keuangan, dan penelitian oleh Anis Fitriani (2013) juga menunjukkan bahwa biaya lingkungan tidak berpengaruh terhadap kinerja keuangan.

\section{Pembahasan}

Pembahasan dalam penelitian ini dilakukan untuk menjabarkan dari hasil pengujian penelitian yang telah dilakukan dengan program SPSS terhadap variabel independen dan variabel dependen yang terakit dalam penelitian ini. Hasil pembahasan lebih lanjut dari hasil pengolahan data dengan SPSS dapat diketahui sebagai berikut:

\section{Pengaruh Kinerja Lingkungan terhadap Profitabilitas}

Berdasarkan hasil uji hipotesis menunjukkan bahwa hipotesis 1 ditolak, dimana hasil yang diperoleh yaitu nilai signifikan sebesar $0,506>$ alpha 0,05 . Jadi, dari hasil pengolahan data dapat disimpulkan bahwa kinerja lingkungan tidak memiliki pengaruh positif terhadap profitabilitas.

Penelitian ini tidak sejalan dengan penelitian yang dilakukan oleh Aldilla Noor Rakhiemah dan Dian Agustia (2009), Sudaryanto (2011), dan Fitriyani (2012) yang menemukan 
bahwa kinerja lingkugan berpengaruh signifikan positif terhadap profitabilitas perusahaan. Semakin besar kinerja lingkungan maka akan semakin tinggi pula profitabilitas suatu perusahaan.

Hasil penelitian ini didukung oleh penelitian Angela (2015) yang menunjukkan bahwa kinerja lingkungan tidak berpengaruh positif terhadap pengungkapan kinerja keuangan. Hasil penelitian oleh Annisa (2018) juga menyatakan bahwa kinerja lingkungan tidak terbukti berpengaruh terhadap profitabilitas. Hal ini dikarenakan baik atau buruknya kinerja lingkungan yang dilakukan perusahaan tidak mempengaruhi meningkatnya profitabilitas.Hasil ini juga diperkuat oleh Anshari (2015) yang menyatakan bahwa perusahaan merasa melakukan penilaian terhadap kinerja lingkungan ini tidak mempengaruhi psosisi dan kompensasi yang diterimanya.Hasil serupa juga diungkapkan oleh Eka \& Novi (2016) menyatakan bahwa tuntutan terhadap kinerja lingkungan yang dilakukan perusahaan lebih ditujukan terhadap perusahaan dengan ukuran besar bukan kepada perusahaan dengan protifabilitas tinggi.

Alasan ditolaknya hipotesis ini dikarenakan meskipun rata-rata pada perusahaan telah memperoleh peringkat biru yang berarti perusahaan melakukan upaya untuk pengelolaan lingkungan sesuai aturan undang-undang. Namun, hasil kinerja lingkungan bisa dibilang cukup belum bisa menjamin profitabilitas perusahaan akan meningkat. Dari hasil penelitian informasi yang telah dikeluarkan oleh kementerian lingkungan hidup tentang kinerja lingkungan tidak dapat mempengaruhi profitabilitas.

Teori stakeholder menyatakan bahwa semua stakeholder mempunyai hak memperoleh informasi mengenai aktivitas perusahaan yang dapat mempengaruhi pengambilan keputusan mereka. Para stakeholder dapat memilih untuk tidak menggunakan informasi tersebut dan bahkan tidak dapat memainkan peran secara langsung dalam suatu perusahaan (Deegan, 2004). Hal ini disebabkan stakeholder dianggap dapat mempengaruhi tapi juga dapat dipengaruhi perusahaan. Namun hasil penelitian ini belum mampu menarik keinginan stakeholder untuk menanam modal di perusahaan. Dimana adanya asupan modal akan menjadikan perusahaan dapat menggunakannya baik untuk kegiatan operasional ataupun produksi umtuk peningkatan profitabilitas.

\section{Pengaruh Biaya Lingkungan terhadap Profitabilitas}

Berdasarkan hasil uji hipotesis menunjukkan bahwa hipotesis 2 ditolak, dimana hasil yang diperoleh yaitu nilai signifikan sebesar $0,476>$ alpha 0,05 . Jadi, dari hasil pengolahan data dapat disimpulkan bahwa biaya lingkungan tidak memiliki pengaruh positif terhadap profitabilitas.

Penelitian ini tidak sejalan dengan penelitian yang dilakukan oleh Sundari (2012), Chiang (2015), dam Al Sharairi yang menyatakan bahwa biaya lingkungan berpengaruh positif tehadap kinerja perusahaan.Hasil temuan ini berimplikasi adanya konsekuensi yang harus ditanggung perusahaan terkait beban moral untuk mengeluarkan biaya lingkungan untuk mencegah terjadinya kerusakan atau memperbaiki kerusakan lingkungan akibat dari kegiatan bisnis yang dilakukan perusahaan.

Hasil penelitian ini didukung oleh penelitian Hadi (2011) yang menyatakan bahwa biaya lingkungan tidak berpengaruh terhadap kinerja keuangan. Hal ini karena tanggung jawab sosial perusahaan lewat berbagai dimensi biaya lingkungan kurang memiliki konsekuensi ekonomi. Perusahaan melakukan tanggung jawab sosial lewat berbagai pengorbanan sosial lebih dilihat dari perspektif dan motif manajemen, kurang memperhatikan dan memperhitungkan kebutuhan stakeholder.Kemudian penelitian yang dilakukan oleh Camilia (2016) menyatakan bahwa ada kalanya perusahaan akan mengabaikan biaya lingkungan yang dikeluarkan, sehingga menimbulkan pengaruh terhadap laporan keuangan tahunan perusahaan yang tidak akan terlihat. 
Hal serupa juga diungkapkan oleh Fitriani (2013) yang menyatakan bahwa biaya lingkungan tidak berpengaruh signifikan terhadap profitabilitas perusahaan.

Alasan ditolaknya hipotesis ini dikarenakan perusahaan yang memiliki profitabilitas tinggi belum tentu lebih banyak mengeluarkan biaya lingkungan, lalu mengungkapkan di laporan tahunan perusahaan. Selama periode penelitian ini juga ditemukan bahwa perusahaan memiliki profitabilitas yang yang tidak stabil setiap tahunnya sehingga biaya lingkungan yang dikeluarkan tidak berpengaruh positif terhadap profitabilitas. Menurut Susenohaji (2003) biaya lingkungan adalah baiya yang dikeluarkan perusahaan berhubungan dengan program perbaikan lingkungan karena pencemaran lingkungan yang dilakukan perusahaan dengan sengaja atau tidak disengaja. Namun, perusahaan menganggap biaya lingkungan hanya menjadi tambahan pengeluaran bagi perusahaan yang akhirnya menjadi pengurang laba perusahaan. Dan dalam penelitian ini jugamenunjukkan bahwa belum tentu biaya lingkungan yang baik berbanding lurus dengan peningkatan profitabilitas.

Teori legitimasi menyatakan bahwa perusahaan secara berkesinambungan harus memastikan apakah mereka telah beroperasi di dalam norma-norma yang dijunjung masyarakat dan memastikan bahwa aktivitas mereka bisa diterima pihak luar (dilegitimasi). Perusahaan merasa keberadaan dan aktivitasnya akan mendapat status dari masyarakat atau lingkungan jika perusahaan melakukan pengungkapan sosial, sehingga perusahaan tersebut beroperasi atau dapat dikatakan sudah terlegitimasi (Adhima, 2012). Dengan perusahaan yang dapat dikatakan sudah terlegitimasi maka citra atau nama baik perusahaan akan menjadi baik di mata masyarakat, lebih lanjut membuat kepercayaan stakeholder pada perusahaan dapat bertambah, dimana biaya lingkungan ini adalah salah satu upaya perusahaan untuk bisa terlegitimasi. Namun hasil penelitian ini belum menunjukkan bahwa biaya lingkungan yang dikeluarkan tidak serta-merta menyebabkan perusahaan terdorong untuk meningkatkan profitabilitas. Data biaya lingkungan yang terdapat dalam penelitian ini merupakan mayoritas dalam kategori rendah, yang artinya perusahaan tidak mencantumkan biaya lingkungan pada laporan tahunan perusahaan.

\section{SIMPULAN, KETERBATASAN DAN SARAN Simpulan}

Berdasarkan hasil penelitian mengenai pengaruh kinerja lingkungan dan biaya lingkungan terhadap profitabilitas maka dapat diambil kesimpulan sebagai berikut :

1. Kinerjalingkungantidakberpengaruh positif terhadapprofitabilitas pada perusahaan manufaktur yang terdaftar di BEI tahun 2014-2018.

2. Biaya lingkungan tidak berpengaruh positif terhadap profitabilitas pada perusahaan manufaktur yang terdaftar di BEI tahun 2014-2018.

\section{Keterbatasan}

Keterbatasan pada penelitian ini terdapat pada hasil analisis adjusted $\mathrm{R}$ square yang menyatakan bahwa 10\% variasi profitabilitas dapat dijelaskan oleh kedua variabel independen pada penelitian ini yakni kinerja lingkungan dan biaya lingkungan, sedangkan 90\% variasi profitabilitas dapat dijelaskan oleh variabel independen yang lain.

\section{Saran}

Berdasarkan keterbatasan yang telah diuraikan diatas, penelitian ini jauh dari kata sempurna.Maka daripada itu, saran dapat digunakan untuk dilakukan penelitian selanjutnya agar didapatkan hasil yang baik. Saran untuk peneliti selanjutnya yaitu sebagai berikut: 
1. Penelitian selanjutnya diharapkan memilih variabel independen lain kecuali kedua variableindependen seperti pengaruh kepemilikan sahamrasio keuangan, ukuran perusahaan, dan kategori investasi.

2. Penelitian selanjutnya bisa menggunakan hipotesis yang lebih mendukung penelitian atau menunjukkan pengaruh yang lebih signifikan antar variabel.

\section{DAFTAR PUSTAKA}

Agustia, L. 2010. Pengaruh Karakteristik Perusahaan terhadap Luas Pengungkapan Informasi Keuangan pada Website Perusahaan.Skripsi . Universitas Negeri Semarang, Semarang.

Al Sharairi, J.A. 2005. The Impact Of Environmental Costs on The Competitive Advantage of Pharmaceutical Companies in Jordan. Middle Eastern Finance and Economics. ISSN: 1450-2889 Issue15.

Andewi, Milind and Suneeta. 2015. The Effect of GHG Emission, Environmental Performance on Financial Performance of Listed Manufacturing Firms In Indonesia. Journal. Procedia - Social and Behavioral Science 211: 461-470

Angela, Dessy. 2015. The Effect of Environmental Performance And Corporate Social Responsibility Disclosure Towards Financial Performance (Case Study to Manufacture, Infrastructure, And Service Companies That Listed At Indonesia Stock Exchange). Procedia - Social and Behavioral Sciences 211 ( 2015 ) 348 - 355

Babalola, Yisau Abiodun. 2012. The Impact of Corporate Social Responsibility on Firms' Profitability in Nigeria. European Journal of Economics, Finance and Administrative Sciences.

Baridwan, Zaki. (2000). Intermediete Accounting.Yogyakarta.BPFE.

Brigham, Eugene dan Joel F Houston, (2006). Manajemen Keuangan II. Jakarta:Salemba Empat.

Burhany, D. I. 2011.Pengaruh Implementasi Akuntansi Lingkungan terhadap Kinerja Lingkungan dan Pengungkapan Informasi Lingkungan serta Dampaknya Terhadap Kinerja Keuangan Perusahaan. Indonesian Journal of Economics and Business 1(2)

Camilia, I. 2016. Pengaruh Kinerja Lingkungan dan Biaya Lingkungan Terhadap Kinerja Keuangan Perusahaan Manufaktur. Skripsi. Sekolah Tinggi Ilmu Ekonomi Perbanas.

Chang, Kai. 2015. The impacts of environmental performance and propensity disclosure on financial performance :Empirical evidence from unbalanced panel data of heavypollution industries in China. Journal of Industrial Engineering and Management, JIEM, 2015 - 8(1): 21-36 - Online ISSN: 2013-0953 - Print ISSN: 2013-8423 http://dx.doi.org/10.3926/jiem.1240

Chariri dan Imam Gozali.(2007). Teori Akuntansi. Edisi Ketiga. Semarang: Universitas Diponegoro

Deddy Supriady Bratakusumah, Dadan Solihin (2004). Otonomi Penyelenggaraan Pemerintah Daerah, Jakarta : Gramedia Pustaka

Deegan, C dan Rankin, M. 1996. The Materiality of Environmental Information to Users of Annual Report.Accounting, Auditing and Accountibility Journal, 10, (4), hlm.562-580.

Deegan, C. (2004). Financial Accounting Theory. McGraw-Hill Book Company. Sydney.

Dessy and Rosita. 2015. The Effect of Environmental Performance And Corporate Social Responsibility Disclosure Towards Financial Performance (Case Study to Manufacture, Infrastructure, And Service Companies That Listed At Indonesia Stock Exchange). Procedia - Social and Behavioral Science 211: 348-355. 
Detiknews.(2019, 08 agustus). Pabrik bercerobong asap selama 2019. Diakses pada 29 desember 2019 dari https://m.detik.com/news/berita/d-4657171/dlh-dki-tegur-47-pabrikbercerobong-asap-selama-2019

Ellimaki, Pia. 2019. Do global firms increase their environmental disclosure and performance? Symbolic verses effective operation and the moderating role of liability of origin. Legitimation implications.Industrial Marketing Management,https://doi.org/10.1016/j.indmarman.2019.10.015

Received31May2019;Receivedinrevisedform23September2019;Accepted25October2019

Eva Sriviana dan Nur Fadjirih Asyik. 2013. Pengaruh Pengungkapan Corporate Social Responsibility dan Ukuran Perusahaan Terhadap Profitabilitas. Jurnal Ilmu \& Riset Akuntansi. Vol. 2 No. 4

Fitriani, A. 2013. Pengaruh Kinerja Lingkungan dan Biaya Lingkungan Terhadap Kinerja Keuangan Pada BUMN. Jurnal Ilmu Manajemen, 1(1), 137-148

Fitriyani \& Siti Mutmainah. 2010. Keterkaitan Kinerja Lingkungan, Pengungkapan Corporate Social Responsibility (CSR) dan Kinerja Finansial. Skripis.Universitas Negeri Semarang, Semarang

G. Sugiyarso dan F. Winarni. (2005). Manajemen Keuangan. Yogyakarta: Media Pressindo Ghozali dan Chariri, (2007). Teori Akuntansi. Semarang: Badan Penerbit Undip.

Hackston, David and Markus J. Milne. 1996. Some Determinants of social and Enviromental Disclosure in New Zealand Companies. Accounting Auditing and Accountability Journal.Vol. 9, No. 1, p. 77-108

Hadi, Nor. (2011). Corporate Social Responsibility.Yogyakarta : Graha Ilmu

Hansen dan Mowen.(2007). Manajerial Accounting (Akuntansi Manajerial).Edisi 8. Jakarta: Salemba Empat.

Hansen, D.R., \& Mowen M.M. (2009). Akuntansi Manjerial, Buku 2, Edisi 8.

Harahap, Sofyan Syafri. (2008). Analisis Kritis Atas Laporan Keuangan.Raja Grafindo Persada, Jakarta

.(2011). Teori Akuntansi Edisi Revisi 2011. Jakarta: Rajawali Pers.

Harianjogja.(2019, 08 januari). Opini Green Accounting di Pusaran Polusi. Diakses pada 29 September 2019 dari https://opini.harianjogja.com/read/2019/08/01/543/1009284/opinigreen-accounting-di-pusaran-polusi

Horne, James C. Van dan John M wachowicz, Jr. (2012). Prinsip-prinsip Manajemen Keuangan (Edisi 13).Jakarta : Salemba Empat

Ikatan Akuntan Indonesia (2009), Pernyataan Standar Akuntansi Keuangan. Jakarta: Salemba Empat

Kasmir, (2008). Analisis Laporan Keuangan, Jakarta:Rajawali Pers

.(2012). Analisis Laporan Keuangan. Jakarta : PT Raja Grafindo Persada Financial Accounting Standards Board (FASB), 1978, Statement of Financial Accounting Concepts No.1 : Objectives of Financial Reporting by Business Enterprises, Stamfort, Connecticut. .(2009). Analisis Laporan Keuangan.Raja Grafindo Persada, Jakarta.

Kementrian Lingkungan Hidup (menlh).2014, Hasil Penilaian PROPER 2013.Diakses 25 April 2016 http://www.mwnlh.go.id/DATA/PROPER2014.PDF.

Kementrian Lingkungan Hidup (menlh).2015, Hasil Penilaian PROPER 2014.Diakses 25 April 2016 http://www.mwnlh.go.id/DATA/PROPER2015.PDF.

Kompas.(2016, 05 september). Green Accounting berbasis aspek berkelanjutan. Diakses pada 29 September 
darihttps://www.kompasiana.com/padlah86933/5b74e6366ddcaela2748b323/greenaccounting-berbasis-aspek-berkelanjutan?page $=$ all

Li,Suhong. 2017. Understanding the impact of green initatives and green performance on financial performance in the US. Business Strategy and the Environment, Bus. Strat.Env. 2017 Published online in Wiley Online Library (wileyonlinelibrary.com) DOI: 10.1002/bse. 1948

Lindrianasari, Yuztitya. 2016. Environmental Management Activity toward Financial Performance in Indonesian Mining Companies. International Journal of Lingkungan dan Keberlanjutan [IJES] ISSN 1927-9566 Vol. 5 No 1, pp. 76-85 (2016)

Mindarwasih, Penni.2001. Perlakuan Biaya Pengolahan Limbah : studi kasus di Rumah Sakit Panti Rapih Yogyakarta. Skripsi.Universitas Sanata Dharma Yogyakarta.

Muhadi dan Siswanto, Joko.(2001). Akuntansi Biaya 1.Yogyakarta.Kanisius.Perusahaan Dengan Corporate Social Responsibility (CSR) Disclosure

Purwanto.(2011). Evaluasi Hasil Belajar. Yogyakarta: Pustaka Belajar

S. Munawir. (2004). Analisis Laporan Keuangan. Yogyakarta: Liberty .(2005), Analisis Laporan Keuangan, Yogyakarta: Liberty.

Santoso, Singgih. (2012). Panduan Lengkap SPSS Versi 20. Jakarta: PT Elex Media Komputindo. Sekaran, Uma. (2011). Metode Penelitian untuk Bisnis.Jakarta: Salemba Empat.

Sihotang, dkk.(2012). Critical Thinking.Jakarta : Pustaka Sinar Harapan

Suchman, Mark C. 1995. Managing Legitimacy: Strategic and Institutional Approaches.The Academy of Management Review Vol. 20 No. 3. pp. 571-610

Sugiyono.(2008). Metode Penelitian Bisnis. Bandung: Alfabeta. .(2009). Metode Penelitian Bisnis. Bandung: Alfabeta. .(2010). Metode Penelitian Bisnis. Bandung: Alfabeta. .(2012). Metode Penelitian Bisnis. Bandung: Alfabeta. .(2013). Metode Penelitian Bisnis. Bandung: Alfabeta.

Suharto,(2008). Edi. Kebijakan Sosial Sebagai Kebijakan Publik.Bandung: Alfabeta.

Sukrisno.Agoes dan Cenik Ardana.(2009). Etika Bisnis dan Profesi, Jakarta.Salemba 4.

Sulistyowati, Firma. 1999. Pelaporan Akuntansi Lingkungan: Perlakuan, Pengukuran, dan Penyajian Biaya Lingkungan Dalam laporan keuangan Perusahaan. Widya Dharma. Edisi April

Susenohaji. 2003. Enviromental Management Accounting (EMA): memposisikan biaya lingkungan sebagai informasi strategis bagi manajemen. Balance, Vol.1

Syamsuddin, Lukman. 2009. Manajemen Keuangan Perusahaan: Konsep Aplikasi dalam: Perencanaan, Pengawasan, dan Pengambilan Keputusan. Jakarta: Rajawali Pers.

Tunggal W.S.P., \& Fachrurrozie. (2014). Pengaruh Environmental Performance, Environmental Cost dan CSR Disclosure Terhadap Financial Performance.Accounting Analysis Journal, 3 (3), 310-320.

Tzouvanas, Panagiotis. 2019. Environmental and financial performance in the European manufacturing sector. An analiysis of extreme tail dependency.The British Accounting Review, PII: S0890-8389(19)30088-5 DOI:https://doi.org/10.1016/j.bar.2019.100863

Undang - Undang RI No.23 tentang pengelolaan lingkungan hidup.

Wardah. 2015. Analisis Pengaruh Penerapan Green Accounting Terhadap Profitabilitas Perusahaan Manufaktur yang Terdaftar di Bursa Efek Indonesia. Skripsi. Universitas Gunadarma 